\title{
Comparative toxicity of several botanical oils against the adults of Sitophilus oryzae
}

\author{
Mohamed M. Azab ${ }^{1}$, Ahmed A. Darwish' ${ }^{1}$, Abeer, A. Salem², and Sawsan H. Abdel-gawad ${ }^{2}$ \\ 1. Plant Protection Dept., Fac. of Agric., Benha Uni., Qalubia, Egypt. \\ 2. Plant Protection Res. Institute, Agric. Res. Center, Ministry of Agric., Giza, Egypt. \\ Corresponding author: mohamed.azab@fagr.bu.edu.eg
}

\begin{abstract}
Bioassay tests were carried out to evaluate the toxicity of garlic, jojoba, clove, mustard, camphor and ginger oils against the adults of Sitophilus oryzae (L.). The insecticidal activity of the oils was investigated for 14 days under $28 \pm 2^{\circ} \mathrm{C}$. The results indicated that a variation in the toxicity of tested botanical oils against the adults of Sitophilus oryzae was found, according to their median lethal concentration $\left(\mathrm{LC}_{50}\right)$ the toxicity order of these oils was garlic > jojoba > clove > mustard > camphor > ginger. The values of LC $_{50}$ ranged between $0.150 \%$ and $2.194 \%(\mathrm{v} / \mathrm{w})$ which were recorded after 7 days of the treatment. The least value of $\mathrm{LC}_{50}(0.045 \%)$ was obtained against the insect tested when garlic oil was applied on wheat grains for 14 days.
\end{abstract}

Key words: garlic, jojoba, clove, mustard, camphor, ginger, median lethal concentration

\section{Introduction}

Stored-product insects are serious pests of dried, stored, durable agricultural commodities and of many value-added food products and nonfood derivatives of agricultural products worldwide. Stored-product insects can cause serious postharvest losses, estimated from up to $9 \%$ in developed countries to $20 \%$ or more in developing countries (Rajendran and Sriranjini, 2008), but they also contribute to contamination of food products through the presence of live insects, insect products such as chemical excretions or silk, dead insects and insect body fragments, general infestation of buildings and other storage structures.

Rice weevil Sitophilus oryzae L. (Coleoptera: Curculionide) is very common pest infesting on many flours, cereals, meal, grains etc. It has worldwide distribution and is among the most economically important stored product pests (Aitken, 1975; Weston and Rattlingourd, 2000; Pugazhvendon et al., 2009 and Matthews, 1993). For the control of these insect pests many synthetic insecticides and fumigants are used, but their widespread use led to some serious problems including development of insect resistance to insecticides (Zettler and Cuperus, 1990; Ribeiro et al., 2003), toxic residues in food, toxicity to consumers and increasing coast of application (Sighamony et al., 1990). The uncontrolled use of these synthetic pesticides caused great hazards for environment and consumers due to residual property (White, 1995). However, there is an urgent need to develop safe alternatives that are of low cost, convenient to use and environmentally friendly (Hassanali et al., 1990; Jember et al., 1995).

The use of essential oils extracted from aromatic plants to control the stored product insects has been investigated and is well documented. There is an urgent need to develop safe alternatives that have the potential to replace the toxic fumigants, yet are effective, economical and convenient to use (Ayvaz et al., 2008). Many spices and herbs, and their extracts, are known to possess insecticidal properties that are frequently present in the essential oil fraction (Brattsten, 1983; Schmidt et al., 1991; Shaaya et al., 1991). Most of the essential oil constituents are Mono terpenoids, which are secondary plant chemicals and considered to be of little metabolic importance. The toxicity of a large number of essential oils and their constituents have been evaluated against a number of stored-product insects Over the past 15 years, interest in botanical insecticides has increased as a result of environmental concerns and insect populations becoming resistant to conventional chemicals. Botanical insecticides are naturally occurring insecticides that are derived from plants (Isman, 2000). The insecticidal activity of essential oils and plant extracts against different stored-product pests has been evaluated

(Shaaya et al., 1991; Sarac and Tunc, 1995; Kim et al., 2003; Lee et al., 2003; Cetin and Yanikoglu, 2006).

The present study aimed to evaluate the toxicity of the plant oils of garlic, jojoba, clove, mustard, camphor and ginger against the adults of Sitophilus oryzae at $28 \pm 2^{\circ} \mathrm{C}$ in the laboratory.

\section{Materials and Methods}

\section{Insects}

Laboratory strain of the rice weevil, Sitophilus oryzae L. (Coleoptera: Curculionidae) was used as an adult stage in these experiments. This insect was reared in glass jars (approx. $250 \mathrm{ml}$ ), each jar contained (about $200 \mathrm{~g}$ ) wheat kernels (variety Shandaweel1) and covered with muslin cloth and 
fixed with a rubber band. Insect cultures were kept under controlled conditions of $28 \pm 1^{\circ} \mathrm{C}$ and $65 \pm 5 \%$ $\mathrm{RH}$ in the rearing room of the laboratory. Wheat grains were treated by freezing at $-18^{\circ} \mathrm{C}$ for 2 weeks before application to eliminate any possible infestation by any insect species (El-lakwah et al., 2004). The moisture content of the grains was around $14 \%$. Three hundred of $S$. oryzae adults (1-2 weeks old) were introduced into the jars for laying eggs then kept at $28 \pm 1{ }^{\circ} \mathrm{C}$ and $65 \pm 5 \% \mathrm{RH}$. Three days later, all insects were separated from the food, and the jars were kept again at the controlled conditions in the rearing room. This procedure was repeated several times in order to obtain a large number of the adults needed to carry out the experiments during this study.

\section{Botanical oils}

Six essential oils are showed in Table (1) belonging to different families; Lauraceaea; Buxaceae; Brassicaceae ; Alliaceae; Zingiberaceae and Myrtaceae were used during these investigations. All the essential oils were bought from Al-Gomhuria Company of drugs, chemicals and medical supplies in Egypt. Garlic oil (Allium sativum); mustarde oil (Brassica nigra); jojoba oil (Simmondsia chinesis); colove oil (Syzygium aromaticum); gingar oil (Zingiber officinale); Camphor oil (Cinnamonum camphora).

Table 1. The botanical oils used in the investigation

\begin{tabular}{|c|c|c|c|c|}
\hline \multirow{2}{*}{ Scientific name } & \multirow{2}{*}{ Family } & \multicolumn{2}{|c|}{ Oil common name } & \multirow{2}{*}{ Used part } \\
\hline & & English & Arabic & \\
\hline Allium sativum $L$. & Alliacae & Garlic & الثوم & Seeds \\
\hline Brassica nigra & Brassicacae & Mustard & الخردل & Seeds \\
\hline Simmondsia chinesis & Buxacae & Jojoba & الجوجوبا & Fruits \\
\hline Syzygium aromaticum & Myrtacea & Clove & القرنفل & Leaves \\
\hline Zingiber officinale & Zingiberaca & Ginger & الزنجبيل & Roots \\
\hline Cinnamonum camphora & Lauracea & Camphor & الكافور & Leaves \\
\hline
\end{tabular}

\section{Bioassay tests}

Wheat grains $(10 \mathrm{~g})$ were treated with $1 \mathrm{ml}$ of various concentrations mixed well and then left for two hrs. to evaporate the solvent (acetone) to obtain the following concentrations $2,1,0.5,0.25$ and $0.125 \%$ (v/w) ( in garlic oil, jojoba oil, clove oil and mustard oil), while camphor oil concentrations were $4,2,1,0.5$ and $0.25 \%(\mathrm{v} / \mathrm{w})$ and ginger oil concentrations were $6,4,2,1$ and $0.5 \%(\mathrm{v} / \mathrm{w})$. Thirty adults of the insect tested (1-2 weeks old) were added to the treated grains. In control tests, the food was treated with the solvent only. Three replicates were carried out for each treatment. The treated grains were kept at the same rearing conditions. Mortalities were recorded at 1, 2, 3, 5, 7, 10 and 14 days after treatment. The adults were removed from the jars after 14 days holdings periods.

\section{Statistical analysis}

Mortality percentages were corrected by Abbott's formula (Abbott, 1925). A probit computer program of Noack and Reichmuth and Finney was used to determine the lethal times for the insecticides (Noack and Reichmuth, 1978; Finney, 1971). A significant difference between $\mathrm{LT}_{50}$ values was based on overlap of $95 \%$ confidence intervals (Aydin and Gürkan, 2006).

\section{Results and Discussion}

Toxicity of tested botanical oils against the adult of $S$. oryzae at $28 \pm 2^{\circ} \mathrm{C}$ and $65 \pm 5 \%$ R.H.
Results of lethal concentrations of the tested botanical oils against the adult of $S$. oryzae indicated that these values depend on the exposure period. Table (2) showed that the lethal concentrations of garlic oil, at 7 days of the treatment, $\mathrm{LC}_{50}$ was $0.150 \%(\mathrm{v} / \mathrm{w})$ which decreased significantly after 14 days to $0.045 \%, \mathrm{LC}_{90}$ was $1.566 \%$ at 7 days of the treatment which decreased to $0.300 \%$ after 14 days of the treatment. The results clearly showed that $S$. oryzae was sensitive to garlic oil.

Table (3) revealed that the lethal concentrations of jojoba oil, $\mathrm{LC}_{50}$ value was $0.171 \%$ at 7 days after treatment, this value reduced to $0.052 \%$ after 14 days of the treatment, $\mathrm{LC}_{90}$ was $5.655 \%$ after 7 days of the treatment which decreased to $0.423 \%$ after 14 days of the treatment.

Table (4) indicated that the lethal concentrations of clove oil, after 7 days of the treatment, $\mathrm{LC}_{50}$ was $0.337 \%$, this value decreased to $0.132 \%$ after 14 days of the treatment, $\mathrm{LC}_{90}$ was 5.782 after 7 days of the treatment which decreased to $1.207 \%$ after 14 days of the treatment.

Table (5) showed that the lethal concentrations of mustard oil, after 10 days of the treatment, $\mathrm{LC}_{50}$ was $0.377 \%$, this value reduced to $0.219 \%$ after 14 days of the treatment, $\mathrm{LC}_{90}$ was $4.585 \%$ after 10 days of the treatment which decreased to $1.558 \%$ after 14 days of the treatment.

Table (6) revealed that the lethal concentrations of camphor oil, after 7 days of the treatment, $\mathrm{LC}_{50}$ was $0.854 \%$, this value decreased to $0.332 \%$ after 14 days of the treatment, $\mathrm{LC}_{90}$ was $7.733 \%$ after 7 days of the treatment which decreased to $1.724 \%$ after 14 days of the treatment. 
Table (7) showed that the lethal concentrations of ginger oil, at 7 days of the treatment, $\mathrm{LC}_{50}$ was $2.194 \%(\mathrm{v} / \mathrm{w})$ which decreased significantly after 14 days to $1.238 \%, \mathrm{LC}_{90}$ was $16.332 \%$ at 7 days of the treatment which decreased to $1.338 \%$ after 14 days of the treatment.

The results showed that garlic oil was the most effective on the insect, which has the least value of $\mathrm{LC}_{50}(0.045 \%)$ after 14 days of the treatment. The toxicity order of remain oils was jojoba, clove, mustard, camphor and ginger.

The results coincide with the reports of other authors investigating the biological activity of essential oils and other plant products towards cereal storage pests, according to Nawrot and Olejarski (2002), botanical oils can be well used against storage and glasshouse pests (aphids, red spidermites and beetles) and sanitary pests (housefly and cockroaches). Oils obtained from different plants have a different composition and concentration of components, which is connected with a varied effect on insects; they can act as insect repellents, discourage from feeding, as well as affect the growth process, disturbing or inhibiting it, which can lead to death. The activity of many botanical oils might be due to monoterpenoids (Waliwitiya et al. 2005; Tong and Coats, 2010). From the former studies on the insecticidal and repellent activity of monoterpenoids and phenolic acids, it can be stated that common chemicals found in plant oils, such as monoterpenoids, 1,8- cineole, alpha pinene, carvone, linalool, etc., and phenolic acids were responsible for the insecticidal activity of these oils (Rani, 2012). In addition, the germanium gave contact toxicity during 4 weeks in $T$. castaneum. The major compounds were citronellol and geranial $(26.14 \%$ and $23.19 \%$, respectively). Three other terepenes were secondary important; linalool, citronellol formate and menthone (Gonzalez et al., 2014). Also, previous studies revealed that the toxicity of botanical oils obtained from aromatic plants against insect pests related to several main components, such as 1.8-cineole, carvacrol, eugenol, limonene, $\alpha$-pinene and thymol. For example, the botanical oils from seeds of Coriandrum sativum, and Carum carvi L. were investigated for their toxicity against $S$. oryzae, it was found that coriander contained linalool as the main product active against the insects. Also, Azab and Esmail (2017) studied the toxicity of some botanical oils against the adult of $S$. oryzae, they found that $\mathrm{LT}_{50}$ of cumin oil was the longest, 4.06 days. It followed by geranium and coriander oils that gave 3.91 and 3.24 days for their $\mathrm{LT}_{50 \mathrm{~s}}$, respectively.

Table 2. Toxicity of garlic oil against the adults of $S$. oryzae at $28 \pm 2{ }^{\circ} \mathrm{C}$

\begin{tabular}{|c|c|c|c|c|c|}
\hline \multirow{2}{*}{$\begin{array}{c}\text { Exposure } \\
\text { period } \\
\text { (Days) } \\
\end{array}$} & \multicolumn{3}{|c|}{$\begin{array}{c}\text { Lethal concentrations } \%(v / w) \text { and their } 95 \% \text { confidence } \\
\text { limits }\end{array}$} & \multirow[t]{2}{*}{ Slope \pm SD } & \multirow{2}{*}{$\mathbf{R}$} \\
\hline & $\mathrm{LC}_{50}$ & $\mathrm{LC}_{90}$ & LC95 & & \\
\hline 7 & $\begin{array}{c}0.150 \\
(0.074-0.307)\end{array}$ & $\begin{array}{c}1.566 \\
(0.767-3.199)\end{array}$ & $\begin{array}{c}3.045 \\
(1.491-6.219)\end{array}$ & $1.259 \pm 0.794$ & 0.984 \\
\hline 10 & $\begin{array}{c}0.116 \\
(0.063-0.213)\end{array}$ & $\begin{array}{c}0.527 \\
(0.286-0.971)\end{array}$ & $\begin{array}{c}0.810 \\
(0.440-1.493)\end{array}$ & $1.724 \pm 0.580$ & 0.865 \\
\hline 14 & $\begin{array}{c}0.045 \\
(0.017-0.121) \\
\end{array}$ & $\begin{array}{c}0.300 \\
(0.112-0.808) \\
\end{array}$ & $\begin{array}{c}0.515 \\
(0.192-1.386)\end{array}$ & $1.135 \pm 0.881$ & 1.000 \\
\hline
\end{tabular}

$\mathrm{R}=$ Correlation coefficient of regression line

$\mathrm{SD}=$ Standard deviation of the mortality regression line

Table 3. Toxicity of jojoba oil against the adults of $S$. oryzae at $28 \pm 2{ }^{\circ} \mathrm{C}$

\begin{tabular}{|c|c|c|c|c|c|}
\hline \multirow{2}{*}{$\begin{array}{l}\text { Exposure } \\
\text { period } \\
\text { (Days) }\end{array}$} & \multicolumn{3}{|c|}{$\begin{array}{c}\text { Lethal concentrations } \%(\mathrm{v} / \mathrm{w}) \text { and their } 95 \% \text { confidence } \\
\text { limits }\end{array}$} & \multirow{2}{*}{ Slope \pm SD } & \multirow[b]{2}{*}{$\mathbf{R}$} \\
\hline & $\mathbf{L C}_{50}$ & LC90 & LC95 & & \\
\hline 7 & $\begin{array}{c}0.171 \\
(0.063-0.464)\end{array}$ & $\begin{array}{c}5.655 \\
(2.092-15.286)\end{array}$ & $\begin{array}{c}15.233 \\
(5.635-41.180)\end{array}$ & $0.845 \pm 1.183$ & 0.945 \\
\hline 10 & $\begin{array}{c}0.107 \\
(0.049-0.234)\end{array}$ & $\begin{array}{c}1.305 \\
(0.596-2.855)\end{array}$ & $\begin{array}{c}2.654 \\
(1.213-5.806)\end{array}$ & $1.178 \pm 0.849$ & 0.996 \\
\hline 14 & $\begin{array}{c}0.052 \\
(0.018-0.155)\end{array}$ & $\begin{array}{c}0.423 \\
(0.143-1.254)\end{array}$ & $\begin{array}{c}0.766 \\
(0.258-2.270)\end{array}$ & $0.969 \pm 1.032$ & 0.987 \\
\hline
\end{tabular}

$\mathrm{R}=$ Correlation coefficient of regression line

$\mathrm{SD}=$ Standard deviation of the mortality regression line 
Table 4. Toxicity of clove oil against the adults of $S$. oryzae at $28 \pm 2{ }^{\circ} \mathrm{C}$

\begin{tabular}{|c|c|c|c|c|c|}
\hline \multirow{2}{*}{$\begin{array}{l}\text { Exposure } \\
\text { period } \\
\text { (Days) }\end{array}$} & \multicolumn{3}{|c|}{$\begin{array}{c}\text { Lethal concentrations \% (v/w) and their } 95 \% \text { confidence } \\
\text { limits }\end{array}$} & \multirow[t]{2}{*}{ Slope \pm SD } & \multirow[t]{2}{*}{$\mathbf{R}$} \\
\hline & $\mathbf{L C}_{50}$ & LC90 & $\mathrm{LC}_{95}$ & & \\
\hline 7 & $\begin{array}{c}0.337 \\
(0.134-0.700) \\
\end{array}$ & $\begin{array}{c}5.782 \\
(2.533-13.198) \\
\end{array}$ & $\begin{array}{c}13.291 \\
(5.823-30.339) \\
\end{array}$ & $1.009 \pm 0.991$ & 0.991 \\
\hline 10 & $\begin{array}{c}0.307 \\
(\mathbf{0 . 1 5 5 - 0 . 7 3 0 )}\end{array}$ & $\begin{array}{c}5.197 \\
(2.397-11.271)\end{array}$ & $\begin{array}{c}11.289 \\
(5.206-24.481)\end{array}$ & $1.079 \pm 0.972$ & 0.979 \\
\hline 14 & $\begin{array}{c}0.132 \\
(0.054-\quad 0.324)\end{array}$ & $\begin{array}{c}1.207 \\
(0.491-2.966)\end{array}$ & $\begin{array}{c}2.260 \\
(0.919-5.557)\end{array}$ & $0.988 \pm 1.012$ & 0.987 \\
\hline
\end{tabular}

$\mathrm{R}=$ Correlation coefficient of regression line

$\mathrm{SD}=$ Standard deviation of the mortality regression line

Table 5. Toxicity of mustard oil against the adults of $S$. oryzae at $28 \pm 2{ }^{\circ} \mathrm{C}$

\begin{tabular}{|c|c|c|c|c|c|}
\hline \multirow{2}{*}{$\begin{array}{c}\text { Exposure } \\
\text { period } \\
\text { (Days) }\end{array}$} & \multicolumn{3}{|c|}{$\begin{array}{c}\text { Lethal concentrations } \%(\mathrm{v} / \mathrm{w}) \text { and their } 95 \% \text { confidence } \\
\text { limits }\end{array}$} & \multirow[t]{2}{*}{ Slope \pm SD } & \multirow[t]{2}{*}{$\mathbf{R}$} \\
\hline & $\mathbf{L C}_{50}$ & LC90 & LC95 & & \\
\hline \multirow{2}{*}{10} & 0.377 & 4.585 & 9.310 & \multirow{2}{*}{$1.181 \pm 0.846$} & \multirow{2}{*}{0.994} \\
\hline & $(0.185-0.767)$ & $(2.253-9.330)$ & $(4.575-18.946)$ & & \\
\hline 14 & $\begin{array}{c}0.219 \\
(0.121-\quad 0.398)\end{array}$ & $\begin{array}{c}1.558 \\
(0.860-2.822)\end{array}$ & $\begin{array}{c}2.715 \\
(1.498-4.919)\end{array}$ & $1.506 \pm 0.664$ & 0.999 \\
\hline
\end{tabular}

Correlation coefficient of regression line

$\mathrm{SD}=$ Standard deviation of the mortality regression line

Table 6. Toxicity of camphor oil against the adults of $S$. oryzae at $28 \pm 2{ }^{\circ} \mathrm{C}$

\begin{tabular}{|c|c|c|c|c|c|}
\hline \multirow{2}{*}{$\begin{array}{l}\text { Exposure } \\
\text { period } \\
\text { (Days) }\end{array}$} & \multicolumn{3}{|c|}{$\begin{array}{c}\text { Lethal concentrations } \%(\mathrm{v} / \mathrm{w}) \text { and their } 95 \% \text { confidence } \\
\text { limits }\end{array}$} & \multirow{2}{*}{ Slope \pm SD } & \multirow[t]{2}{*}{$\mathbf{R}$} \\
\hline & $\mathbf{L C}_{50}$ & $\mathrm{LC}_{90}$ & LC95 & & \\
\hline 7 & $\begin{array}{c}0.854 \\
(0.454-1.607)\end{array}$ & $\begin{array}{c}7.733 \\
(4.112-14.543)\end{array}$ & $\begin{array}{c}14.440 \\
(7.678-27.158)\end{array}$ & $1.343 \pm 0.744$ & 0.980 \\
\hline 10 & $\begin{array}{c}0.537 \\
(0.320-0.903) \\
\end{array}$ & $\begin{array}{c}3.041 \\
(1.810-5.110) \\
\end{array}$ & $\begin{array}{c}4.971 \\
(2.958-8.353) \\
\end{array}$ & $1.743 \pm 0.574$ & 0.943 \\
\hline 14 & $\begin{array}{c}0.332 \\
(0.177-0.624)\end{array}$ & $\begin{array}{c}1.724 \\
(0.918-3.235)\end{array}$ & $\begin{array}{c}2.748 \\
(1.464-5.158)\end{array}$ & $1.479 \pm 0.676$ & 0.996 \\
\hline \multicolumn{6}{|c|}{$\begin{array}{l}\mathrm{R}=\text { Correlation coefficient of regression line } \\
\mathrm{SD}=\text { Standard deviation of the mortality regression line }\end{array}$} \\
\hline \multicolumn{6}{|c|}{ Table 7. Toxicity of ginger oil against the adults of $S$. oryzae at $28 \pm 2^{\circ} \mathrm{C}$} \\
\hline \multirow{2}{*}{$\begin{array}{c}\text { Exposure } \\
\text { period } \\
\text { (Days) } \\
\end{array}$} & \multicolumn{3}{|c|}{$\begin{array}{c}\text { Lethal concentrations } \%(v / w) \text { and their } 95 \% \text { confidence } \\
\text { limits }\end{array}$} & \multirow{2}{*}{ Slope \pm SD } & \multirow[t]{2}{*}{$\mathbf{R}$} \\
\hline & $\mathbf{L C}_{50}$ & $\mathrm{LC}_{90}$ & LC95 & & \\
\hline 7 & $\begin{array}{c}2.194 \\
(1.249-3.854)\end{array}$ & $\begin{array}{c}16.332 \\
(9.298-28.688)\end{array}$ & $\begin{array}{c}28.853 \\
(16.426-50.683)\end{array}$ & $1.512 \pm 0.661$ & 0.861 \\
\hline 10 & $\begin{array}{c}1.238 \\
(0.628-2.443)\end{array}$ & $\begin{array}{c}6.949 \\
(3.522-13.710)\end{array}$ & $\begin{array}{c}11.332 \\
(5.743-22.357)\end{array}$ & $1.233 \pm 0.811$ & 0.968 \\
\hline 14 & $\begin{array}{c}0.943 \\
(1.496-0.595)\end{array}$ & $\begin{array}{c}1.338 \\
(2.122-0.844)\end{array}$ & $\begin{array}{c}4.591 \\
(7.279-2.895)\end{array}$ & $2.099 \pm-0.476$ & 0.993 \\
\hline
\end{tabular}

$\mathrm{R}=$ Correlation coefficient of regression line

$\mathrm{SD}=$ Standard deviation of the mortality regression line 


\section{References}

Abbott W. S. (1925): A method of computing the effectiveness, of an insecticide. $J$ Econ Entomol.;18:265-267.

AitkenAD(1975): Insect Travelers.I: Coleoptera .Techn.Bull.,31. H.M.S.O.London:pp. 190. Sci 56:696-702 J Stored Prod Res 44:145-151

Aydin H., Gürkan M. O. (2006): The efficacy of spinosad on different strains of Spodoptera littoralis (Boisduval) (Lepidoptera: Noctuidae). Turk J Biol.;30:5-9.

Ayvaz , A .; Albayrak , S and Karaborklu , S ( 2008). Gamma radiation sensitivity of the larvae and pupae of Indian meal moth Plodia interpunctella (Hübner) (Lepidoptera: Pyralidae). Pest Management Science

Azab M. M. and Esmail M. E. (2017): Influence of some botanical oils on effectiveness of controlled atmosphere of elevated carbon dioxide on adults of Sitophilus oryzae. Asian Journal of Advances in Agricultural Research, 4 (2): 1-12. DOI: 10.9734/AJAAR/2017/38471

Brattsten , L . B (1983): Cytochrome P-450 involvement in the interactions Between plant terpenes and insect herbivores. In: Hedin PA, editor. Plant Resistance to Insects. pp. 173-195. ACS Symposium Series No. 208, American Chemical Society

Cetin, H and Yanikoglu , A ( 2006): A study of the larvicidal activity Of Origanum(Labiatae) species from Southwest Turkey Journal of VectorEcology31: 118-122.

El-lakwah F. A., Azab M. M. and Ebrahim W M K. (2004): Influence of temperature on the effectiveness of controlled atmospheres of various carbon dioxide concentrations or high nitrogen content on two stored products insects. Annals Agric Sci Moshtohor.;42:839 850.

Finney D. J. (1971): Probit analysis. 3rd. Eddn, Cambridge University press: Cambridge, UK.

Gonzalez J. O. W., Gutierrz M. M., Ferrero A. A., Banol B. F. (2014): Essential oils nanoformulations for stored product pest controleharacterization and biological properties. Chemosphere.;100:130-138.

Hassanali A, Lwande W, Ole-Sitayo N, Moreka L,Nokoe S, Chapya A(1990): Weevil repellent constituents of Ocimum suave leaves and Eugenia caryophylla cloves used as grain protectant in parts of East Africa. Disc. Inno: 2: 91-95.

Isman , M . B (2000): Plant essential oils for pest and disease management . Crop Protection 19: 603608
Jembere B, Obeng-Ofori D, Hassanali A, NyamasyoGNN (1995): Products derived from the leaves of Ocimum kilimanndscharium (Labiatae) as post-harvest grain protectants against the infestation of three major stored product insect pests. Bulletin of Entomological Research: 85:361 - 367.

Kim, S. I.; Park, C.; Ohh , M .H .;Cho, H .C and Ahn , Y. J (2003): Contact and fumigant activities of aromatic plants extracts and essential oils against Lasioderma serricorne (Coleoptera: Anobiidae). Journal of Stored Products Research 39: 11-19

Lee, B.H.; Annisb, P.C.; Tumaaliia, F. and Choic, W.S. (2003): Fumigant toxicityof essential oils from the Myrtaceae family and 1,8-cineole against 3 major stored-grain insects. J.Stored Prod. Res., 40: 553-564.

Matthews GA., G.A. and Hislop, E.C.( 1993): Insecticide application in the stores.In Matthews (eds.).Application technology for crop protection. CAB, Londonpp.305-315.

Nawrot J., Olejarski P., eteryczne O. (2002): nowe perspektywy produkcji naturalnych insektycydów. Ochr.Roślin 11:4-5.

Nawrot J., Olejarski P., Olejki eteryczne (2002):nowe perspektywy produkcji naturalnych insektycydów. Ochr.Roślin 11:4-5.

Noack S., Reichmuth C. H. (1978): Einrechnerisches Verfahren zur Bestimmung von beliebigen Dosiswerten eines Wirkstoffes aus empirischen Dosis-Wirkungs-Daten. Mitteilungen aus der Biologischen Bundesanstalt für Land- und Fortswirtschaft, Berlin-Dahlem, Heft.

Pugazhvendon SR, Elumalai K, Ronald Ross P, Soundararajan M. (2009): Repellent activity of chosen plant species against Tribolium castaneum. World Journal of Zoology 4(3): 188190.

Rajendran S. and Sriranjini V. (2008): Plant products as fumigants for stored-product insect control. J Stored Prod Res.; 44:126-135.

Rani P. U. (2012): Fumigant and contact toxic potential of essential oils from plant extracts against stored product pests. J Biopest.;5:120128.

Ribeiro BM, Guedes RNC, Olivira EE, Santos JP (2003): Insecticidal resistance and synergism in Brasilian populations of Sitophilus zeamais (Coleoptera: Curculionidae). Journal of Stored Products Research.: 39:21-31.

Sarac, A and Tunc, I( 1995): Toxicity of essential oil vapours to stored-product insects Zeitschrift für Pflanzenkrankheiten und Pflanzenschutz 102: 429-434 
Schmidt, G . H .; Risha , E . M and Nahal ,A . K . M( 1991):Reduction of progeny of some stored products Coleoptera by vapours of Acorus calamus oil. Journal of Stored Products Research 21: 121-127.

Shaaya, E.; Ravid, U.; Paster, N.; Juven, B.; Zisman, U and Pissarev, V (1991): Insecticidal activity of essential oils against four major stored product insects. Journal of Chemical Ecology 17: 499-504

Sighamony S, Anees I, Chandrakala T, KaiserJamil, S (1990): Indigenous plant products as grain protectants against Sitophilus Oryzae (L) and Rhyzopertha dominica (F). Journal of Stored Products Research 22: 21-23.

Tong F., Coats J. R. (2010): Effects of monoterpenoid insecticides on $[3 \mathrm{H}]-\mathrm{TBOB}$ binding in house fly GABA receptor and $36 \mathrm{Cl}-$ uptake in American cockroach ventral nerve cord. Pestic Biochem Physiol.;98:317-324.
Waliwitiya R., Isman M. B., Vernon R. S., Riseman A. (2005): Insecticidal activity of selected monoterpenoids and rosemary oil to Agriotes obscurus. (Coleoptera: Elateridae). J Econ Entomol.;98:1560-1565.

Weston PA, Rattlingourd PA(2000): Progeny production by Tribolium castaneum (Coleoptera: Tenebrionidae) and Oryzaephilus surinamensis (Coleoptera: Silvanidae) on maize previously infested by Sitotroga cerealla(Lepidoptera: Gelechiidae).ournal of Economic Entomology.: 93: 533-5.

White L. (1995): Chemical control.Integrated management of insects in stored products. Dekker, Inc;New York. Basel. Hong Kong.: pp. 287- 330.

Zettler JL, Cuperus GW( 1990): Pesticide resistance in Tribolium castaneum (Coleoptera: Tenebrionidae) and Rhyzopertha dominica (Coleoptera: Bostrichidae) in wheat. Journal of Economic Entomology.: 83:1677- 1681. 